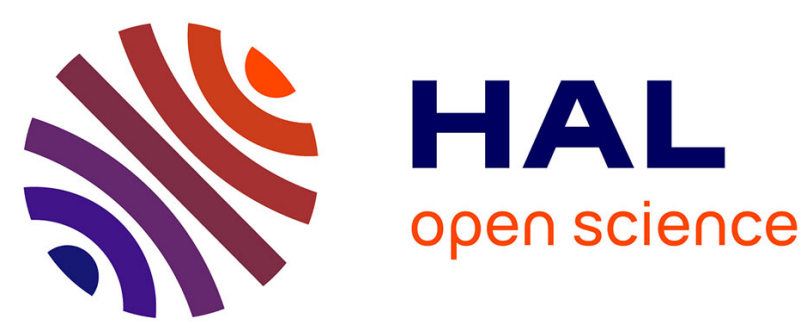

\title{
Tuning the electron storage potential of a charge-photoaccumulating Ru II complex by a DFT-guided approach
}

Nicholas Randell, Julia Rendon, Martine Demeunynck, Pierre-alain Bayle, Serge Gambarelli, Vincent Artero, Jean-marie Mouesca, Murielle

Chavarot-kerlidou

\section{To cite this version:}

Nicholas Randell, Julia Rendon, Martine Demeunynck, Pierre-alain Bayle, Serge Gambarelli, et al.. Tuning the electron storage potential of a charge-photoaccumulating $\mathrm{Ru}$ II complex by a DFT-guided approach. Chemistry - A European Journal, 2019, 25 (61), pp.13911-13920. 10.1002/chem.201902312 . hal-02326894

\section{HAL Id: hal-02326894 \\ https://hal.science/hal-02326894}

Submitted on 18 Oct 2021

HAL is a multi-disciplinary open access archive for the deposit and dissemination of scientific research documents, whether they are published or not. The documents may come from teaching and research institutions in France or abroad, or from public or private research centers.
L'archive ouverte pluridisciplinaire HAL, est destinée au dépôt et à la diffusion de documents scientifiques de niveau recherche, publiés ou non, émanant des établissements d'enseignement et de recherche français ou étrangers, des laboratoires publics ou privés. 


\title{
Tuning the electron storage potential of a charge-photoaccumulating Ru(II) complex by a DFT-guided approach.
}

\author{
Nicholas M. Randell, ${ }^{\mathrm{a}}$ Julia Rendon, ${ }^{\mathrm{a}, \mathrm{b}}$ Martine Demeunynck, ${ }^{\mathrm{c}}$ Pierre-Alain Bayle, ${ }^{\mathrm{d}}$ Serge \\ Gambarelli, ${ }^{\mathrm{b}}$ Vincent Artero, ${ }^{\mathrm{a}}$ Jean-Marie Mouesca, ${ }^{\mathrm{b}}$ Murielle Chavarot-Kerlidou*a \\ Email: murielle.chavarot-kerlidou@cea.fr
}

${ }^{a}$ Univ. Grenoble Alpes, CNRS, CEA, Laboratoire de Chimie Biologie des Métaux, 38000 Grenoble, France.

${ }^{\mathrm{b}}$ Univ. Grenoble Alpes, CEA, CNRS, IRIG-DIESE-SyMMES-CAMPE, 38000 Grenoble, France.

${ }^{\mathrm{c}}$ Univ. Grenoble Alpes, CNRS, DPM, 38000 Grenoble, France.

${ }^{\mathrm{d}}$ Univ. Grenoble Alpes, CEA, CNRS, IRIG-DEPHY-MEM-RM, 38000 Grenoble, France.

Keywords. Charge photoaccumulation, computational chemistry, energy conversion, ruthenium chromophore.

\begin{abstract}
Molecular photosensitizers that are able to store multiple reducing equivalents are of great interest in the field of solar fuel production, where most reactions involve multielectronic reduction processes. In order to increase the reducing power of a ruthenium tris-diimine chargephotoaccumulating complex, two structural modifications on its fused dipyridophenazinepyridoquinolinone ligand were computationally investigated. Addition of an electron-donating oxime group was calculated to substantially decrease the reduction potentials of the complex, thus
\end{abstract}


guiding the synthesis of a pyridoquinolinone-oxime derivative. Its spectroscopic and (spectro)electrochemical characterization experimentally confirmed the DFT predictions, especially with the first and second reduction processes cathodically-shifted by -0.24 and -0.14 $\mathrm{V}$, respectively, compared to the parent complex. Moreover, the ability of this novel artificial photosynthetic system to store two photogenerated electrons at a more reducing potential, via a proton-coupled electron transfer mechanism, was demonstrated.

\section{Introduction}

In recent decades, as awareness of both anthropogenic climate change and shrinking petroleum supplies has grown, scientists have searched for ways to transition society away from its dependence on fossil fuels. This effort has accelerated the growth of the field of solar fuels research. ${ }^{[1-4]}$ Solar fuels, such as $\mathrm{H}_{2}, \mathrm{CO}$, and formic acid, can be produced via light-driven reduction processes using abundant feedstock chemicals such as $\mathrm{CO}_{2}$ and $\mathrm{H}_{2} \mathrm{O}$. Most of these transformations involve the transfer of multiple electrons, and significant progress has been made in developing molecular catalysts able to perform such kinetically arduous multi-proton multielectron processes. ${ }^{[5-8]}$ Widely-used photosensitizers (PS) for solar fuel production include $\mathrm{Ru}(\mathrm{II})^{[9-11]}$ and $\operatorname{Ir}(\mathrm{III})^{[12,13]}$ polypyridyl coordination complexes, porphyrins, ${ }^{[14-16]}$ and organic push-pull dyes. ${ }^{[17-19]}$ While these chromophores feature broad absorption bands with relatively high extinction coefficients in the visible region, they fundamentally generate one photoexcited electron at a time. This implies that, for catalysis to occur, the system needs to accumulate electrons generated by sequential light absorption steps; this leads to excessive charge build-up and generates intermediate species prone to quench the PS excited state by reverse electron transfer or by energy

transfer. ${ }^{[20-22]}$ In addition, the catalytic rate should be fast enough in order to avoid competing reactions, typically charge recombination. The latter however take place at very fast timescales (fs 
to $\mathrm{ns}$ ) compared to catalysis ( $\mu$ s to $\mathrm{ms}$ range for $\mathrm{H}_{2}$ production, ${ }^{[23]}$ typically). This represents a major issue for solar fuel-producing systems, and developing novel systems specifically designed to optimizing this charge accumulation process can provide a way to address this problem.

In nature, photosynthesis decouples catalysis from light-driven processes thanks to specific cofactors, such as plastoquinones or $\mathrm{NAD}(\mathrm{P})^{+}$, stepping in to relay photogenerated electrons two by two. Notably, stable reduced derivatives (dihydroquinones and NADPH) are generated thanks to a storage mechanism involving proton-coupled electron transfers (PCET). Taking inspiration from these systems, more sophisticated light-harvesting units, capable of storing multiple electrons upon visible light irradiation, have been synthesized and studied. ${ }^{[20-22]}$ Two conceptually different molecular designs have proven successful in storing multiple reducing equivalents in artificial photosynthetic systems: either the system assembles multiple chromophores each of which independently transfers electrons to the acceptor site (such as a bridging ligand between two chromophore units), ${ }^{[24-37]}$ or it contains a single chromophore and relies on a sacrificial electron donor to perform multiple excitation-accumulation cycles. ${ }^{[38-45]}$ In the latter case, either a single or multiple electron storage sites can be assembled adjacent to the chromophore. Typical lightharvesting units are porphyrins, ${ }^{[24,36]} \operatorname{Ir}(\mathrm{III})^{[37]}$ or $\mathrm{Ru}(\mathrm{II})$ polypyridine ${ }^{[25-35,38-45]}$ complexes, covalently linked to a wide variety of electron storage sites, such as a metal centre, ${ }^{[25]}$ polyoxometalates, ${ }^{[13,36]}$ naphthalene diimide,${ }^{[35,45]}$ perylene diimide, ${ }^{[24]}$ anthraquinone,${ }^{[30,33,34]}$ or $\pi$ extended phenanthroline-based ${ }^{[26-29,44,46,47]}$ ligands. Recently, Wenger and coworkers produced one of the first examples of the beneficial role played by electron photoaccumulation in photoredox catalysis. They used assemblies of $\mathrm{Ru}(\mathrm{II})$ chromophores with a central dibenzo[1,2] dithiin electron storage unit to accumulate two photogenerated electrons, further used to perform dithiolate/disulfide interconversion. ${ }^{[31,32]}$ 
Among these examples, systems relying on a single PS unit to promote unidirectional charge separation and storage on a unique acceptor site are the most likely candidates for the integration of a charge photoaccumulation process into functional systems such as dye-sensitized photocathodes for solar fuels production. ${ }^{[19,48,49]}$ In these devices, the light-harvesting moiety is anchored onto a $p$-type semiconductor film such as $\mathrm{NiO}$, allowing fast reductive quenching of its excited state by hole injection into the semiconductor valence band upon visible light irradiation. By virtue of the unidirectional charge transfer, the electron-storage site is distant from the semiconductor surface, thus preventing back-electron transfer. The electron storage unit could also be bound to a catalyst, to promote catalyst activation and solar fuels production. Molecular chargephotoaccumulating systems answering to this topological requirement are however rather scarce in the literature. ${ }^{[2-45]}$

In 2018, we reported a mononuclear ruthenium tris-diimine complex with an extended phenazine-based ligand $[1]\left(\mathrm{PF}_{6}\right)_{2}($ Scheme 1) which falls into the second category of chargeaccumulating PS. ${ }^{50,51]}$ The phenazine ligand features a tetracyclic pyridoquinolinone subunit inspired by the quinone-based electron storage and relay systems involved in photosynthesis. ${ }^{[52]}$ We demonstrated that $[\mathbf{1}]\left(\mathrm{PF}_{6}\right)_{2}$ is capable of storing two photogenerated electrons upon excitation of the complex with visible light in the presence of a sacrificial electron donor. In the absence of a source of protons, the first reduction of $[1]^{2+}$ occurs at $-0.87 \mathrm{~V}$ and the second at $-1.32 \mathrm{~V}$ vs. the ferrocenium/ferrocene $\left(\mathrm{Fc}^{+} / \mathrm{Fc}\right)$ redox couple; these potentials are low enough to donate electrons to many of the best-performing catalysts for $\mathrm{H}_{2}$ production. In the presence of proton donors, however, the reduction processes become coupled to proton transfers, yielding the stabilized doubly-reduced doubly-protonated species $\left[\mathbf{1 H}_{2}\right]^{2+}$. The occurrence of PCET processes strongly lowers the reducing power of the system, precluding the use of charge photoaccumulation in $\left[\mathbf{1 H}_{2}\right]^{2+}$ to drive catalytic $\mathrm{H}_{2}$ production. This motivated us to search for structurally modified 
derivatives to store electrons at more negative potentials, even after protonation. Using density functional theory (DFT) calculations, we screened electron-rich substituents and selected the introduction of an oxime group in place of the carbonyl moiety in $[1]\left(\mathrm{PF}_{6}\right)_{2}$. Herein we describe the process of this DFT-guided design, the synthesis of the selected oxime-modified PS [2] $\left(\mathrm{PF}_{6}\right)_{2}$ together with its spectroscopic and (spectro)electrochemical characterization. Under irradiation in the presence of a proton source, $[2]^{2+}$ transforms into the doubly-protonated species $\left[\mathbf{2} \mathbf{H}_{2}\right]^{2+}$, which is a stronger reductant than $\left[\mathbf{1 H}_{2}\right]^{2+}$.

\section{Results and Discussion}

In an effort to retain the charge-accumulating properties of $[1]^{2+}$ while increasing the reducing power of the stored electrons, we explored the concept of adding electron-rich groups to the existing extended ligand skeleton of $[1]^{2+}$. The synthesis of $[1]\left(\mathrm{PF}_{6}\right)_{2}$ followed a chemistry on the complex approach $^{[53]}$ in which we adapted procedures previously reported for the synthesis of acridine-based tetracyclic heterocycles ${ }^{[54]}$ to a $\mathrm{Ru}(\mathrm{II})$ trisdiimine framework. This method lends solubility to the otherwise insoluble planar extended ligand system. Given the success of this approach in the synthesis of $[1]\left(\mathrm{PF}_{6}\right)_{2}$, we examined known substitution reactions on the tetracyclic

pyridoquinolinone core ${ }^{[51]}$ to choose suitable electron-rich candidates. ${ }^{[54]}$ Based on this, two electron-donating groups, an oxime $\left([2]^{2+}\right)$ and a methyl sulfide $\left([3]^{2+}\right)$, were selected (Figure 1). 
$[1]^{2+}$

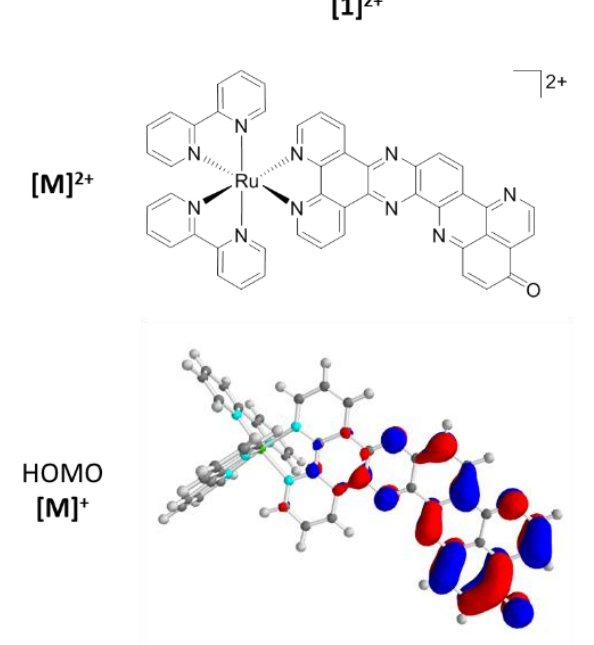

$[2]^{2+}$
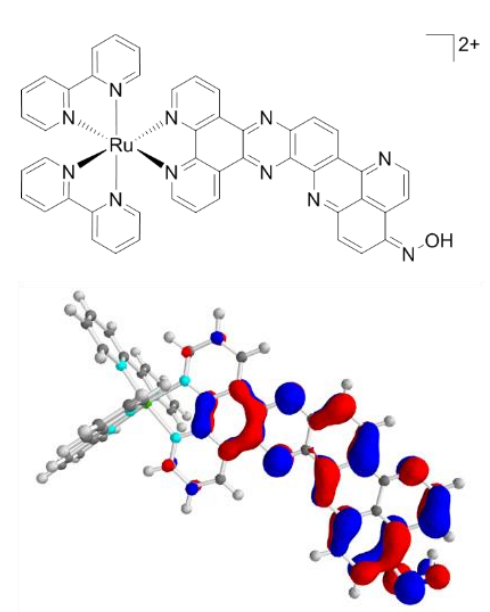

$[3]^{2+}$
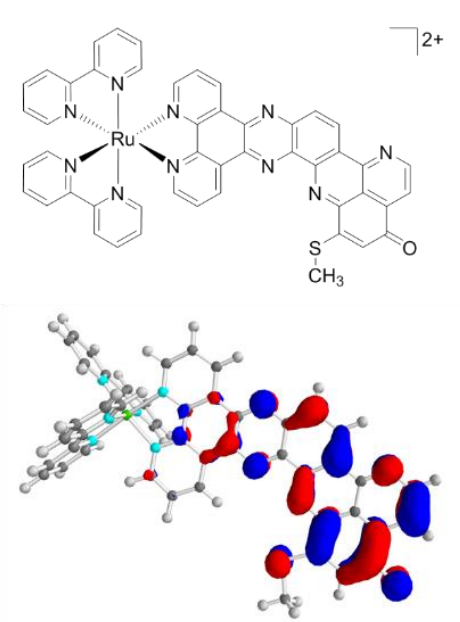

Figure 1. Structures of the parent $[1]^{2+}$ and DFT-investigated [2] ${ }^{2+}$, and $[3]^{2+}$ complexes (top); HOMO isosurfaces of the $[\mathbf{M}]^{+}$singly-reduced states (bottom). Isodensity value: 0.03 a.u.

Rather than synthesize both $[2]^{2+}$ and $[3]^{2+}$, DFT screening was used to predict which substituent would have the greater effect on the redox properties of $[1]^{2+}$. To do this, the first five reduction potentials of $[2]^{2+}$ and $[3]^{2+}$ were calculated relative to those of $[1]^{2+}$ (Table 1 , Scheme S1, Figure S1, Table S1). The addition of an oxime unit $\left([2]^{2+}\right)$ was predicted to have the greatest effect on the reduction potentials; it was calculated to lower the potential of all of the first five reductions by at least $0.1 \mathrm{~V}$. In contrast, the methyl sulfide moiety of $[3]^{2+}$ only lowered the potential of the first reduction, leaving the others unchanged. For this reason, $[2]\left(\mathrm{PF}_{6}\right)_{2}$ was selected to be synthesized.

The orbital isosurfaces of the reduced states (Figures 1, S2) help explaining how the oxime unit of $[2]^{2+}$ affects the second reduction potential of the complex $\left([2]^{+}\right.$to $\left.[2]^{0}\right)$. The electron density on the dipyridophenazine part of the $\pi$-extended ligand is increased in the HOMO of $[2]^{+}$relative to that of $[1]^{+}$(Figure 1), especially on the pyrazine ring where the second reduction process is expected to occur. This causes coulombic resistance to the addition of the second electron, thus lowering the potential of the subsequent reduction of $[2]^{+}$to $[2]^{0}$ relative to the same second reduction of $[1]^{+}$to $[1]^{0}$. By contrast, the HOMO of $[3]^{+}$is very similar to that of $[1]^{+}$, explaining 
why the methyl sulfide group has almost no effect on the second reduction process (calculated $\delta \mathrm{E}^{0}$ of $-0.03 \mathrm{eV}$, see Table 1$)$.

Table 1. Experimental and calculated reduction potentials for $[1]^{2+}$ (in $\mathrm{V} \mathrm{vs} \mathrm{Fc}^{+} / \mathrm{Fc}$ ) and relative calculated potential shifts in reduction for $[2]^{2+}$ and $[3]^{2+}$.

\begin{tabular}{|c|c|c|c|c|}
\hline & \multicolumn{2}{|c|}{$\left[^{1}\right]^{\mathrm{x}}$} & {$\left[^{2}\right]^{\mathrm{x}}$} & {$[3]^{\mathrm{x}}$} \\
\hline $\begin{array}{c}\text { Redox } \\
\text { Process }\end{array}$ & $\begin{array}{c}\text { Exp. }^{[51]} \\
(\mathrm{V})\end{array}$ & $\begin{array}{c}\mathrm{E}^{\circ} \\
(\mathrm{DFT})^{\mathrm{a}} \\
(\mathrm{V})\end{array}$ & $\begin{array}{c}\delta \mathrm{E}^{\circ} \\
(\mathrm{DFT})^{\mathrm{b}} \\
(\mathrm{V})\end{array}$ & $\begin{array}{c}\delta \mathrm{E}^{\circ} \\
(\mathrm{DFT})^{\mathrm{b}} \\
(\mathrm{V})\end{array}$ \\
\hline$\left[\mathbf{M}^{2+} /[\mathbf{M}]^{+}\right.$ & -0.87 & -0.87 & -0.27 & -0.11 \\
\hline$[\mathbf{M}]^{+} /[\mathbf{M}]^{0}$ & -1.32 & -1.44 & -0.17 & -0.03 \\
\hline$[\mathbf{M}]^{0} /[\mathbf{M}]^{1-}$ & -1.81 & -1.63 & -0.33 & -0.01 \\
\hline$[\mathbf{M}]^{1-} /[\mathbf{M}]^{2-}$ & -2.02 & -2.18 & +0.13 & -0.00 \\
\hline$[\mathbf{M}]^{2-} /[\mathbf{M}]^{3-}$ & -2.43 & -2.34 & -0.13 & +0.01 \\
\hline
\end{tabular}

${ }^{a}$ See experimental section and SI (Scheme S1, Figure S1, Table S1). ${ }^{b}$ Redox potential values $[2]^{2+}$ and $[3]^{2+}$ are given relative to those computed for $[1]^{2+}$.

[1] $\left(\mathrm{PF}_{6}\right)_{2}$ was synthesized according to the previously reported chemistry on the complex approach. ${ }^{[51,53]}$ The synthesis of $[2]\left(\mathrm{PF}_{6}\right)_{2}$ was subsequently carried out from $[\mathbf{1}]\left(\mathrm{PF}_{6}\right)_{2}$ and hydroxylamine (in-situ generated from hydroxylamine hydrochloride) in a mixed organic/aqueous solvent mixture (Scheme 1) in good yield. This reaction must be carried out in the dark, owing to the photoreactive nature of $[1]^{2+}$ in solution in the presence of electron donors (such as hydroxylamine). ${ }^{[51]}$

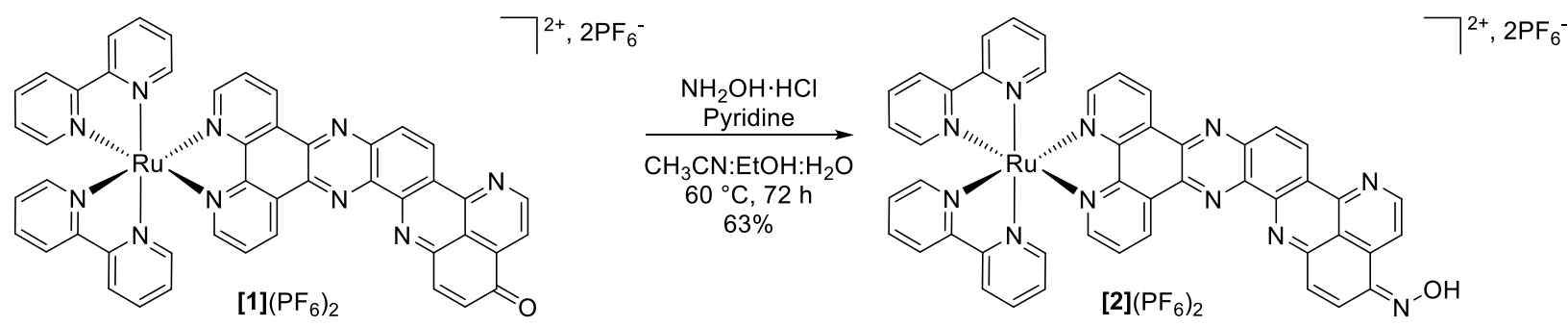

Scheme 1. Synthesis of [2] $\left(\mathrm{PF}_{6}\right)_{2}$ from $[1]\left(\mathrm{PF}_{6}\right)_{2}$. 
The planarity of the extended $\pi$-conjugated ligand in $[2]^{2+}$ promotes the formation of $\pi$-stacked dimers (see Scheme S2) of the complex in solution, as previously observed for $[1]^{2+}$ and related complexes. ${ }^{[46,51,53,55]}$ This tendency to aggregate complicates the characterization of $[\mathbf{2}]^{2+}$ by NMR spectroscopy; indeed, a concentration-dependent shift in the ${ }^{1} \mathrm{H}$ NMR signals of $[2]^{2+}$ (Figure S5) is observed, similar to that previously reported for $[1]^{2+}$. In the case of $[2]^{2+}$, however, the plot of $\log \left(\right.$ Conc. $\left.[2]^{2+}\right)$ vs. chemical shift (Figure S5) does not exhibit any plateau behavior consistent with the presence of either isolated monomers at low concentration, or isolated dimers at high concentration as further aggregation leads to insolubility. In particular, the lack of observable free monomer at the lower limit of detection strongly suggests that the formation of $\pi$-stacked dimers is more energetically favorable for $[2]^{2+}$ than for $[1]^{2+}$. In addition to the $\pi$-stacking of $[2]^{2+}$ in solution, the oxime group on the iminoquinone subunit is capable of tautomerization into the corresponding nitroso form ${ }^{[56]}$ (Scheme S2). In the ${ }^{1} \mathrm{H}$ NMR spectrum of $[2]^{2+}$, the merger of the signals corresponding to the two protons located on the iminoquinone moiety (H16 and H17 - see Scheme S3) into a single singlet at $6.05 \mathrm{ppm}$ is characteristic of this additional dynamic process. Indeed, the tautomerization reaction switches the quinoidal electronic structure (oxime tautomer) to a fully aromatic ring (nitroso tautomer) (see Scheme S3), thus making the electronic environment of H16 and H17 quite dynamic. This behavior was confirmed by temperature-dependent NMR experiments (Figures S6, S7, S8 and Table S2): when the sample is cooled to $268 \mathrm{~K}$ (Figure S7), the singlet at 6.05 begins to separate into two broad signals, which appear to correspond to H16 and H17, although the signals fail to resolve further at lower temperatures. The complex nature of the solution-phase structure of $[2]^{2+}$ led us to the use of DFT-computed screening constants to aid in the signal assignment of the ${ }^{1} \mathrm{H}$ and ${ }^{13} \mathrm{C}$ NMR spectra (see Table S3, Figures S9 and S10). This DFT-assisted assignment demonstrates that, while dynamic processes are occurring in solution, the 
predominant species is the oxime form of $[2]\left(\mathrm{PF}_{6}\right)_{2}$. In order to best characterize its electronic properties, the following electronic spectroscopy and electrochemical experiments were carried out at the lowest possible concentrations permitted experimentally.

The UV/vis absorption spectrum of $[2]^{2+}$ was recorded in acetonitrile (Figure S11). In addition to the intense ligand-centered transition (bpy ligands) at $280 \mathrm{~nm}$, it features a broad band in the visible region, tailing at $600 \mathrm{~nm}$, thus slightly red-shifted with respect to $[1]^{2+}$. According to our previous studies, metal-to-ligand-charge-transfer (MLCT) and ligand-centered $\pi-\pi^{*}$ transitions (on the $\pi$-extended ligand) both contribute to this relatively intense absorption (molar absorptivity of $\left.25000 \mathrm{~L} \cdot \mathrm{mol}^{-1} \cdot \mathrm{cm}^{-1}\right) \cdot{ }^{[50,51]}$

Cyclic (CV) and differential pulse (DPV) voltammetries were used to investigate the electrochemical properties of $[2]\left(\mathrm{PF}_{6}\right)_{2}$ (Figure 2). In Figure 2a, the first reduction of $[2]^{2+}$ is compared to that of $[1]^{2+}$; it is apparent that the first reduction of $[2]^{2+}$ occurs at a substantially lower potential than that of $[\mathbf{1}]^{2+}$. According to the DPV results (Figure 2c), this reduction occurs at $-1.11 \mathrm{~V} v s . \mathrm{Fc}^{+} / \mathrm{Fc}$ in $[2]^{2+}$ compared to $-0.87 \mathrm{~V} v s . \mathrm{Fc}^{+} / \mathrm{Fc}$ for $[1]^{2+}$; this $-0.24 \mathrm{~V}$ experimental shift is in excellent agreement with our DFT calculations (Table 1) which predicted a decrease in reduction potential of $-0.27 \mathrm{~V}$. The second reduction of $[2]^{2+}$ occurs at $-1.46 \mathrm{~V} v s . \mathrm{Fc}^{+} / \mathrm{Fc}$ according to DPV, thus shifted by $-0.14 \mathrm{~V}$ compared to second reduction of $[1]^{2+}(-1.32 \mathrm{~V} v s$. $\mathrm{Fc}^{+} / \mathrm{Fc}$ ); again, this result matches with the DFT-predicted shift for the second reduction process $(-0.17 \mathrm{~V})($ Table 1$)$. The presence of an additional reduction process of very low intensity is also observed at $-1.31 \mathrm{~V}$ (before the second reduction) in the DPV and is tentatively assigned to the presence of $\pi-\pi$ stacked dimer; increased propensity for stacking upon reduction was indeed previously reported $^{[46]}$ and supported by DFT calculations. ${ }^{[51]}$ 

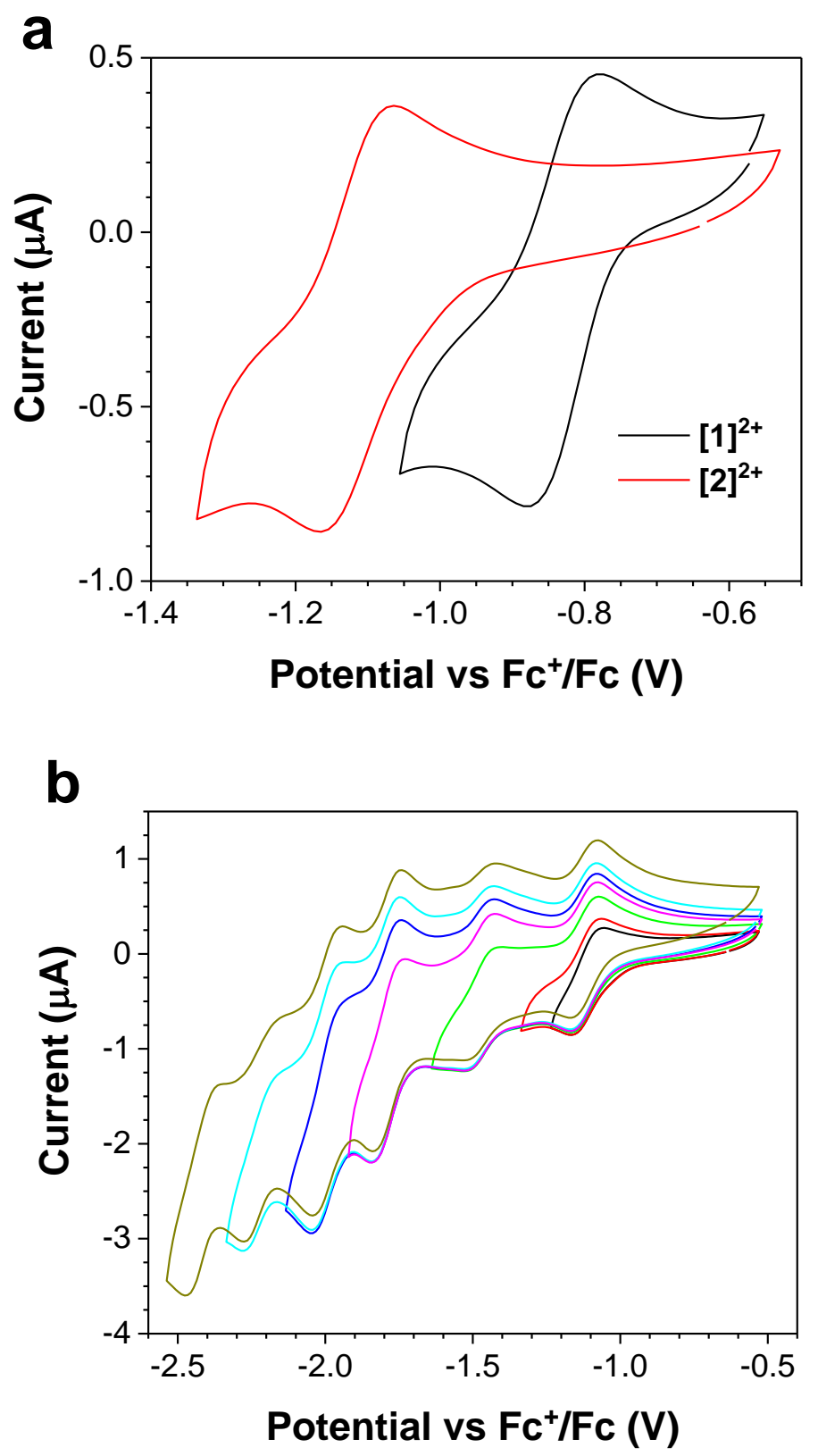


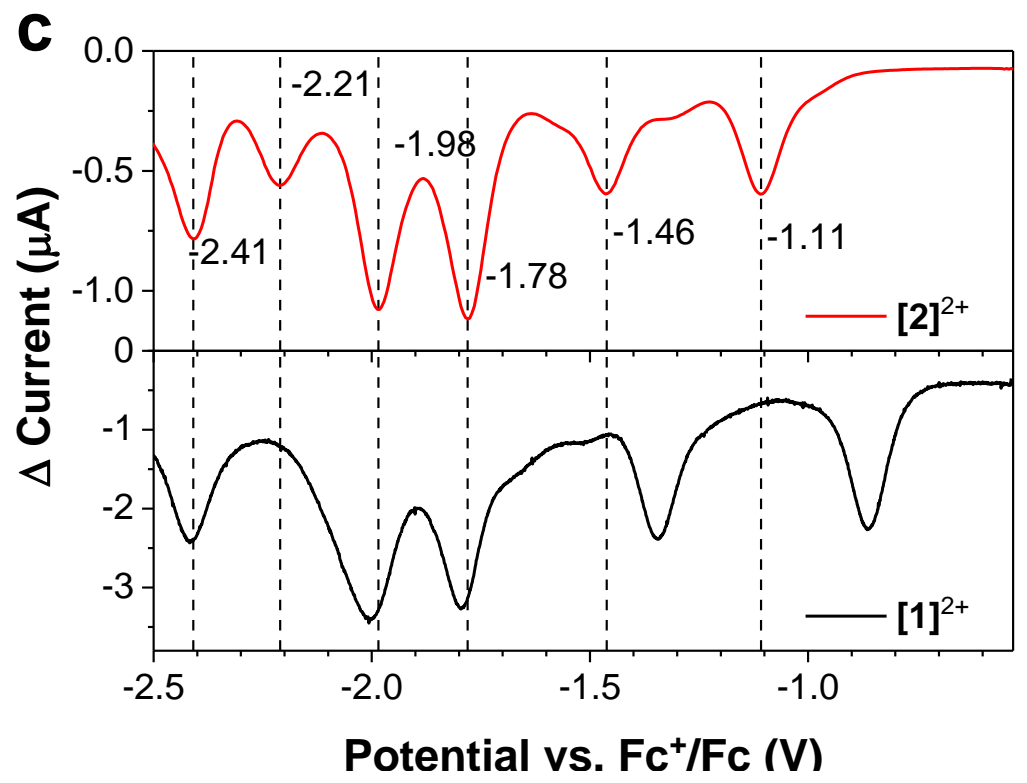

Figure 2. a) Comparison of the first reduction processes of $[1]^{2+}$ and $[2]^{2+} ;$ b) Cyclic voltammograms $(\mathrm{CV})$ of $[2]^{2+}$ on increasing range of cathodic potentials; c) Normalized differential pulse voltammograms (DPV) of $[1]^{2+}$ and $[2]^{2+}$. All voltammograms recorded on a glassy carbon electrode at a complex concentration of $0.25 \mathrm{mM}$ in a dry, degassed $0.1 \mathrm{M} n \mathrm{Bu}_{4} \mathrm{NPF}_{6}$ solution in $N, N$-dimethylformamide (DMF) (CV: scan rate of $100 \mathrm{mV} \cdot \mathrm{s}^{-1}$; DPV: $\mathrm{P}_{\text {Height }}=5 \mathrm{mV}, \mathrm{P}_{\text {Width }}=50$ $\mathrm{ms}, \mathrm{S}_{\text {Height }}=-1 \mathrm{mV}, \mathrm{S}_{\mathrm{T}}=200 \mathrm{~ms}$ ).

At potentials lower than $-1.6 \mathrm{~V} v s$. $\mathrm{Fc}^{+} / \mathrm{Fc}$ (Figure $2 \mathrm{~b}$ and $2 \mathrm{c}$ ), the electrochemical behavior is similar to the previously described one for $[1]\left(\mathrm{PF}_{6}\right)_{2}$, in agreement with reduction processes occurring on the diimine ligands. We noticed the presence of an additional reduction process at $2.2 \mathrm{~V}$, also tentatively assigned to the presence of aggregated species. It is important to highlight here that the first two reductions, which are of primary interest in view of photoaccumulation processes, occur at a lower potential than the previously reported system $[1]\left(\mathrm{PF}_{6}\right)_{2}$, as predicted by the DFT calculations.

In order for a complex to store multiple electrons under light-driven conditions, two important criteria must be met: the intermediate reduced states should be stable, and capable of absorbing visible light to drive an additional reduction process. To test these criteria, the (electro)chemicallyreduced forms of $[2]^{2+}$ were investigated by UV/vis absorption spectroscopy. The oxime complex 
was first reduced using cobaltocene $\left(\mathrm{CoCp}_{2}\right)$ under strictly inert conditions, at low concentration $(0.02 \mathrm{mM})$ in order to minimize the effect of $\pi$-stacking on the results. Addition of up to one equivalent of $\mathrm{CoCp}_{2}$ generated the singly-reduced $[2]^{+}$species, characterized by the growth of a peak at $500 \mathrm{~nm}$ with a shoulder at approximately $635 \mathrm{~nm}$ (Figure 3a). This behavior resembles that of $[1]^{2+}$ which also developed low energy absorption peaks upon single reduction. However, unlike in the chemical reduction of $[1]^{2+},{ }^{[51]}$ there is no further change in the spectrum of $[2]^{+}$upon addition of a second equivalent of cobaltocene. The potential of the $\mathrm{CoCp}_{2}{ }^{+} / \mathrm{CoCp}_{2}$ redox couple is reported to be $c a .-1.3 \mathrm{~V}$ vs. $\mathrm{Fc}^{+} / \mathrm{Fc}$ (in dichloromethane), ${ }^{[57]}$ thus not reducing enough to generate the doubly-reduced species $[2]^{0}$ as the second reduction occurs at $-1.46 \mathrm{~V} v s . \mathrm{Fc}^{+} / \mathrm{Fc}$ according to our DPV experiments.

In addition to chemical reduction, spectroelectrochemical measurements were performed to address the first and second reduction processes (Figure $3 \mathrm{~b}$ and S12). A first controlled potential electrolysis was performed on $[2]^{2+}$ at $-0.75 \mathrm{~V}(v s . \mathrm{Ag} / \mathrm{AgCl})$; (i.e. a potential more negative than that of the $[2]^{2+}$ to $[2]^{+}$reduction, see inset Figure $3 b$ ) and the evolution of the UV/vis absorption spectrum was monitored over 30 min (Figure 3b). The growth of a low energy absorption band centered at $500 \mathrm{~nm}$ with a shoulder at $635 \mathrm{~nm}$ is observed, matching the spectrum obtained by chemical reduction of $[2]^{2+}$. The spectroscopic properties of singly-reduced $[2]^{+}$are thus not affected by the higher concentration $(0.25 \mathrm{mM}$ in DMF) employed for the SEC measurements nor by the presence of the electrolyte salt $\left(0.1 \mathrm{M} \mathrm{nBu}_{4} \mathrm{PF}_{6}\right)$. The reversibility of the $[2]^{2+} /[2]^{+}$redox couple was assessed by poising the working electrode at $+0.1 \mathrm{~V} v$ s. $\mathrm{Ag} / \mathrm{AgCl}$ for $20 \mathrm{~min}$; the resulting spectrum perfectly overlaps with the original one for [2] ${ }^{2+}$ (Figure S12a), in agreement with a full reoxidation process and attesting for the stability of the electrochemically-generated [2] ${ }^{+}$ species. In both the chemical and electrochemical reduction experiments no decrease of the 
absorption is observed between 400 and $500 \mathrm{~nm}$ upon reduction (Figure 3); the light-harvesting efficiency of the system is fully retained in the visible region to generate a reactive excited state.

A second controlled potential electrolysis was performed at $-1.0 \mathrm{~V}$ ( $v s$. $\mathrm{Ag} / \mathrm{AgCl}$ ); (i.e. a potential more negative than that of the [2] $]^{+}$to $[2]^{0}$ reduction, see inset Figure $3 b$ ) and the evolution of the UV/vis absorption spectrum was monitored over 30 min (Figure $3 b$ ). At $-1.0 \mathrm{~V}$, the absorbance spectrum tails to $800 \mathrm{~nm}$ and the features at 500 and $635 \mathrm{~nm}$ broaden when compared to the spectra collected at $-0.7 \mathrm{~V}$ (Figure $3 \mathrm{~b}$ ). The reversibility of the reduction was again assessed by the application of a $+0.1 \mathrm{~V} v s . \mathrm{Ag} / \mathrm{AgCl}$ bias for 15 minutes; when corrected for solvent loss over the course of the experiment the final re-oxidized spectrum matches the initial absorbance of $[2]^{2+}$ well (Figure S12b). The accessibility and reversibility of the second reduction by applied electrochemical potential confirms the fact that $\mathrm{CoCp}_{2}$ did not have sufficient potential to reduce $[2]^{+}$to $[2]^{0}$. These results overall demonstrate that the first and second reductions of $[2]^{2+}$ are both electrochemically reversible, and both reduced states are stable on the scale of minutes to hours. Additionally, both reductions produce changes in the UV/vis absorption spectrum of the complex consistent with those seen in $[1]^{2+}$ both spectroelectrochemically and via chemical reduction. 

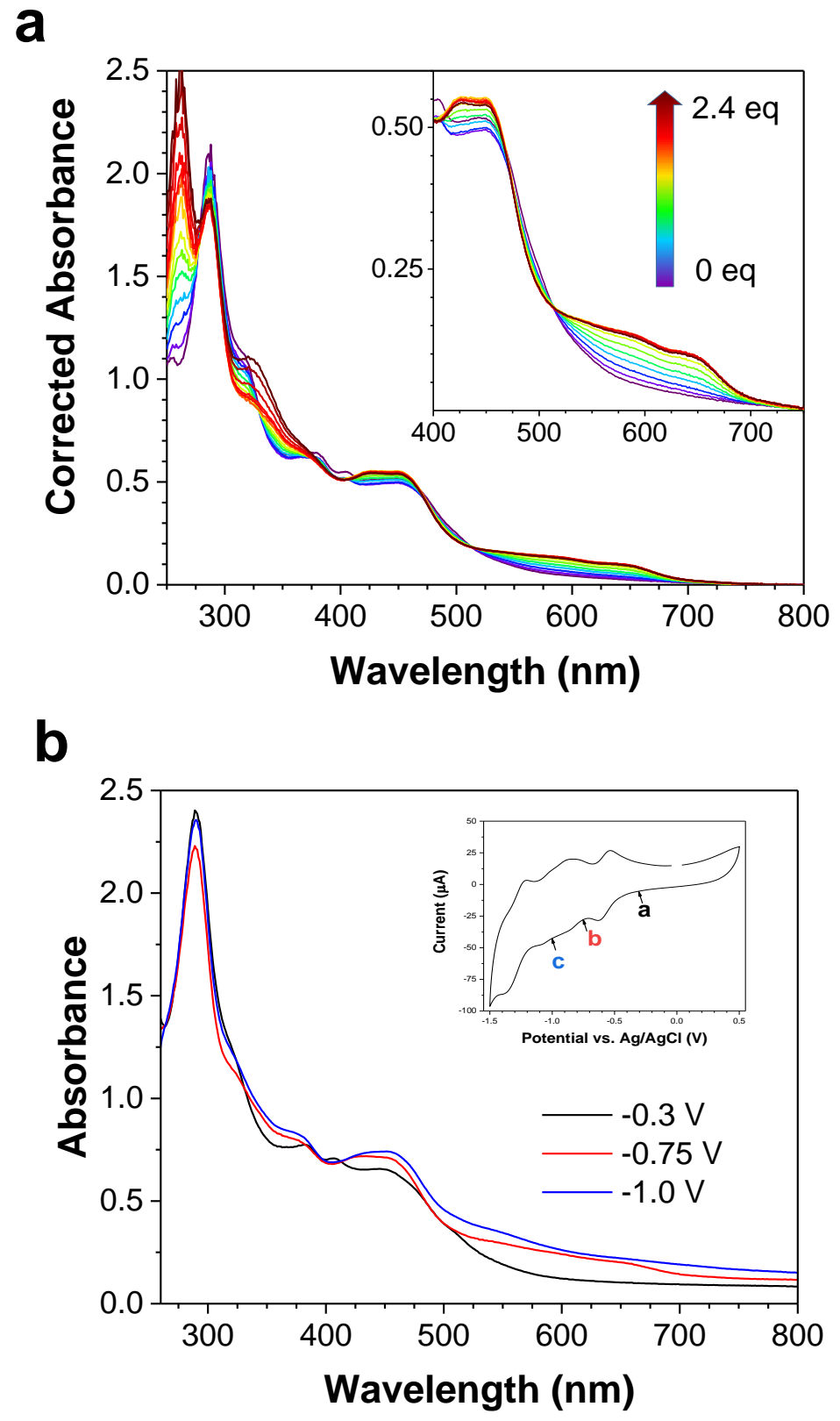

Figure 3. a) UV/Vis absorption monitoring of the chemical reduction of $[2]\left(\mathrm{PF}_{6}\right)_{2}(0.02 \mathrm{mM}$ in $\mathrm{CH}_{3} \mathrm{CN}$ ) by cobaltocene (see SI for experimental details). b) UV/Vis spectra of [2] $\left(\mathrm{PF}_{6}\right)_{2}$ recorded under controlled potential electrolysis conditions ( $0.25 \mathrm{mM}$ in DMF containing $\left.0.1 \mathrm{M} \mathrm{nBu}_{4} \mathrm{NPF}_{6}\right)$ : black line: $-0.3 \mathrm{~V}$, red line: $-0.75 \mathrm{~V}$ (first reduction process) and blue line: $-1 \mathrm{~V}$ (second reduction process), all potentials $v s$. $\mathrm{Ag} / \mathrm{AgCl}$.

The electronic structure of singly-reduced $[2]^{+}$was further investigated by X-band electron paramagnetic resonance (EPR) spectroscopy, using a slightly modified version of the procedure we previously developed to study $[1]^{+} .{ }^{[51]}$ The EPR spectrum of $[2]^{+}$recorded at room temperature 
(Figure 4 black line) features an intense radical signal with an average g value of $\sim 2.003$ and a peak-to-peak line width of $0.5 \mathrm{mT}$, characteristic of an organic radical species (consistent with the signal recorded for $\left.[1]^{+[51]}\right)$. The EPR signal for $[2]^{+}$displays poorly resolved hyperfine splitting compared to the spectrum recorded for $[1]^{+}$, which exhibits well resolved splitting (Figure S13). Such unresolved hyperfine structure can be explained by the presence of additional hyperfine coupling coming from the oxime group (one more hydrogen atom and one more nitrogen atom) relative to the carbonyl functionality in $[1]^{+}$, and could indeed be simulated (Figure $4 a$, red line) as a monoradical coupled to 4 nitrogen and 7 hydrogen atoms (see Table S4 for hyperfine coupling constants). The recorded EPR signals were quantified (see procedure in the experimental section) and represent, for $[1]^{+}$and $[2]^{+}$respectively, only $\sim 50 \%$ and $\sim 15 \%$ of the expected amount of radical. The lack of radical signal strongly suggests the formation of spin-paired dimers $\pi-\left\{[2]_{2}\right\}^{2+}$ (thus EPR silent) at the $0.2 \mathrm{mM}$ concentration employed for the EPR experiments. Such a low amount of radical for $[2]^{+}$, compared to $[1]^{+}$, is in agreement with the increased propensity for $[2]^{2+}$ to form $\pi$-stacked dimers compared to $[1]^{2+}$, as previously observed in the concentration-dependent ${ }^{1} \mathrm{H}$ NMR experiments (Figure S5). This behavior is also consistent with previously reported studies from MacDonnell et al. ${ }^{[29,46,47]}$ Whether this spin-pairing process can result in the formation of a formal C-C bond is however still a matter for debate. ${ }^{[29]}$

Electrochemically-generated $[2]^{0}$ also proved to be EPR-active; its spectrum recorded at room temperature in the electrolyte solution $\left(0.1 \mathrm{M} \mathrm{nBu}_{4} \mathrm{PF}_{6}\right.$ in $\left.\mathrm{DMF}\right)$ displays five equidistant broad lines with 1:2:3:2:1 relative intensity, typical for hyperfine coupling coming from an interaction with two nearly equivalents nitrogen with a coupling constant of approximately $13.8 \mathrm{MHz}$ (Figure 4b). This spectral shape is consistent with that previously reported for the singly-reduced dipyridophenazine complex $\left[\mathrm{Ru}(\mathrm{bpy})_{2}(\mathrm{dppz})\right]\left(\mathrm{PF}_{6}\right)_{2} \cdot{ }^{[51,58]} \mathrm{A}$ similar unexpected result was 
previously obtained for $[1]^{0[51]}$ and might be rationalized by considering the formation of a $\pi-\pi$ stacked dimer $\pi-\left\{[2]_{2}\right\}^{0}$ : in such a structure, the two electrons located on the peripheral pyridoquinolinone-oxime subunits (from the first reduction process) would be spin-paired, and the additional electrons (from the second reduction process) would reside primarily on the phenazine moiety and would be too far from each other to interact within the dimer, thus conferring its paramagnetic character ${ }^{[51]}$ Two different pathways could account for its formation: in the first one, the second reduction step would take place first to yield the doubly-reduced complex $[2]^{0}$ in a triplet spin state, followed by its dimerization to form $\pi-\{[2] 2\}^{0}$. However, any attempts to detect a characteristic EPR signature of the paramagnetic triplet state of $[2]^{0}$ proved unsuccessful, though it is calculated to be slightly more stable (by $0.2 \mathrm{eV}$ in vacuo) than the corresponding diamagnetic singlet state (Figure S2), in line with what was previously calculated for $[1]^{0}{ }^{[51]}$ Alternatively, dimerization could occur immediately after the first reduction process to form the spin-paired dimer $\pi-\left\{[2]_{2}\right\}^{2+}$, followed by the reduction of the phenazine moieties within this dimer to yield $\pi-\left\{[2]_{2}\right\}^{0}$. For both pathways, a contribution from $\pi-\pi$ stacked dimers $\pi$-\{[2]2\} (formally $[2]^{+}+[2]^{0}$ ), in which only one of the two phenazine rings is reduced, cannot be excluded. It should also be emphasized that, taking into consideration the relatively low intensity of the recorded signal (which represents $\approx 4 \%$ of the expected spin concentration), the formation of a high percentage of diamagnetic species (either as monomers or dimers in solution) is plausible to consider. 
a

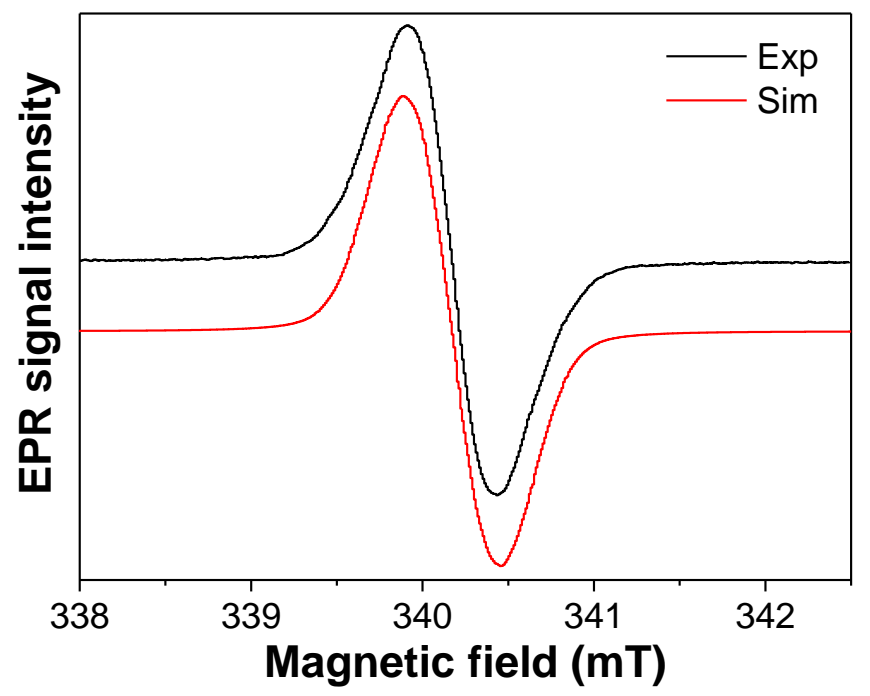

b

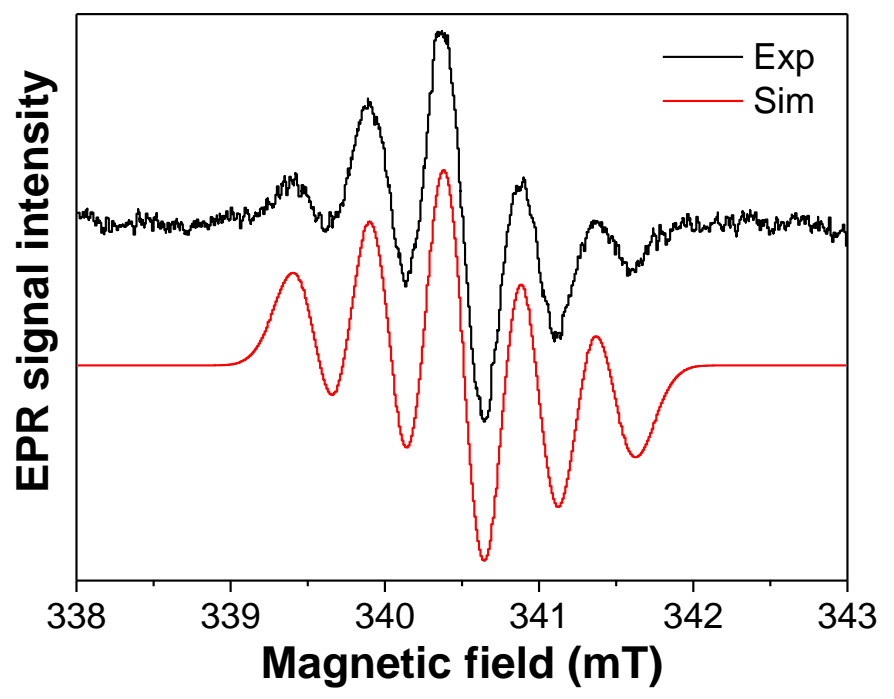

Figure 4. Experimental (black lines) and simulated (red lines) EPR spectra of (a) [2] ${ }^{+}$in $\mathrm{CH}_{3} \mathrm{CN}$, prepared by chemical reduction of $[2]^{2+}$ with one eq. of $\mathrm{CoCp}_{2}$; (b) electrochemically-generated

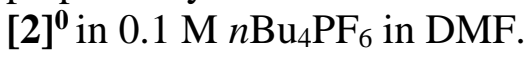

Knowing that the prerequisites have been met for $[2]^{2+}$ to accumulate two electrons, a photolysis experiment was carried out at $0.015 \mathrm{mM}$ in $\mathrm{CH}_{3} \mathrm{CN}$, in the presence of triethylamine as the sacrificial electron donor (Figure 5). Upon visible light irradiation, a decrease in the intensity of the low energy transitions is observed together with the growth of a low energy absorbance tailing to just over $600 \mathrm{~nm}$. After 10 minutes of irradiation, no further spectral change was observed. 

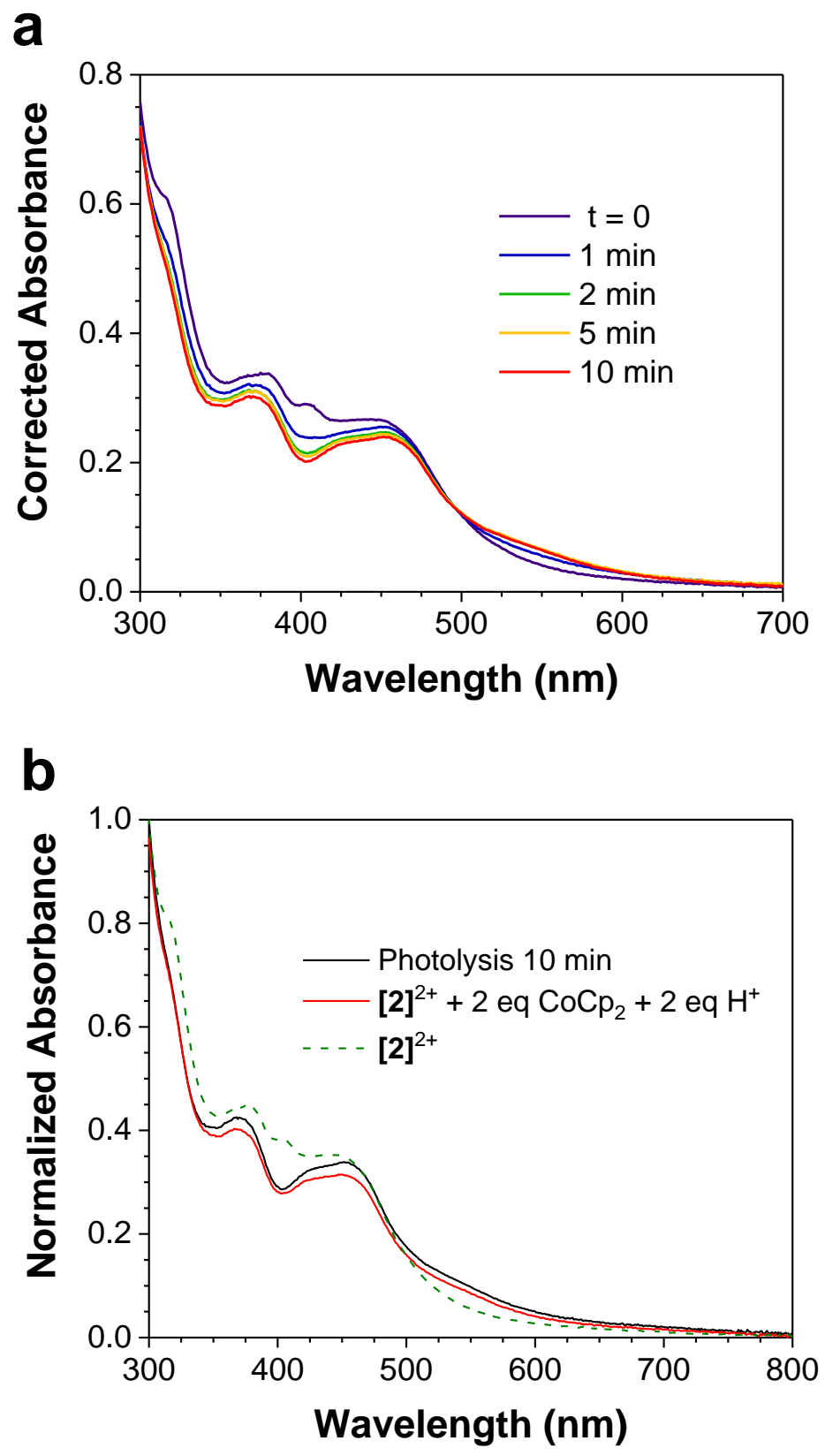

Figure 5. UV-vis monitoring of the photolysis of [2] $\left(\mathrm{PF}_{6}\right)_{2}$ in the presence of triethylamine $\left(0.015 \mathrm{mM}[2]\left(\mathrm{PF}_{6}\right)_{2}\right.$ and $0.16 \mathrm{mM}$ triethylamine in dry, degassed acetonitrile). a) Evolution of UV-vis absorbance spectra during photolysis; b) comparison of the UV-vis spectra of [2](PF6)2, the product after 10 minutes of irradiation in the presence of an electron donor, and the resulting spectrum following chemical reduction with 2 eq. $\mathrm{CoCp}_{2}$ in the presence of 2 eq. TFA.

The final spectrum of the photolysis experiment is not superimposable to the ones recorded either for the singly-reduced species $[2]^{+}$or for the doubly-reduced species $[2]^{0}$ (Figure 3 ). In the case of $[1]^{2+}$, protons released by the decomposition of the TEA radical cation ${ }^{[59]}$ were shown to 
protonate the reduced derivatives to promote a two-electron-two-proton redox process forming $\left[\mathbf{1 H}_{2}\right]\left(\mathrm{PF}_{6}\right)_{2}$ rather than $\left[\mathbf{1}^{0}{ }^{0.51]}\right.$ Thus, in order to identify the novel species formed by photolysis, chemical reduction of $[2]^{2+}$ was performed in the presence of trifluoroacetic acid (TFA) as a proton source. UV/vis absorption spectra were recorded after sequential additions of $\mathrm{CoCp}_{2}$ and TFA to a solution of $[2]\left(\mathrm{PF}_{6}\right)_{2}$ under strictly inert conditions (Figure S14). By contrast with the chemical reduction previously undertaken in the absence of a proton source (Figure 3), spectral changes are now observed upon the addition of a second equivalent of $\mathrm{CoCp}_{2}$. This suggests that chargecompensation through protonation occurs, forming the singly-reduced singly-protonated species $[2 \mathbf{H}]^{2+[60]}$ whose potential is sufficiently shifted to more positive values, with respect to $[2]^{+}$, to thermodynamically allow the second reduction process. After addition of 2 eq. $\mathrm{CoCp}_{2}+2$ eq. TFA, the resulting spectrum overlaps very well with the normalized absorbance spectrum of the photolysis product, thus establishing that two electrons and two protons are stored on [2] $]^{2+}$ under visible-light driven conditions by proton-coupled electron transfer (PCET) processes. The most stable structure for $\left[\mathbf{2 H}_{2}\right]^{2+}$ was calculated to be the $p$-amino-phenylhydroxylamine derivative (Figure 6) supporting a quinone/dihydroquinone-type reduction, as previously reported for $[1]^{2+}$. Upon exposure to air in a dark environment, the initial spectrum of $[2]^{2+}$ was recovered (Figure $\mathrm{S} 15)$, clearly demonstrating that the photoaccumulation process with the oxime complex $[2]\left(\mathrm{PF}_{6}\right)_{2}$ is also fully reversible.
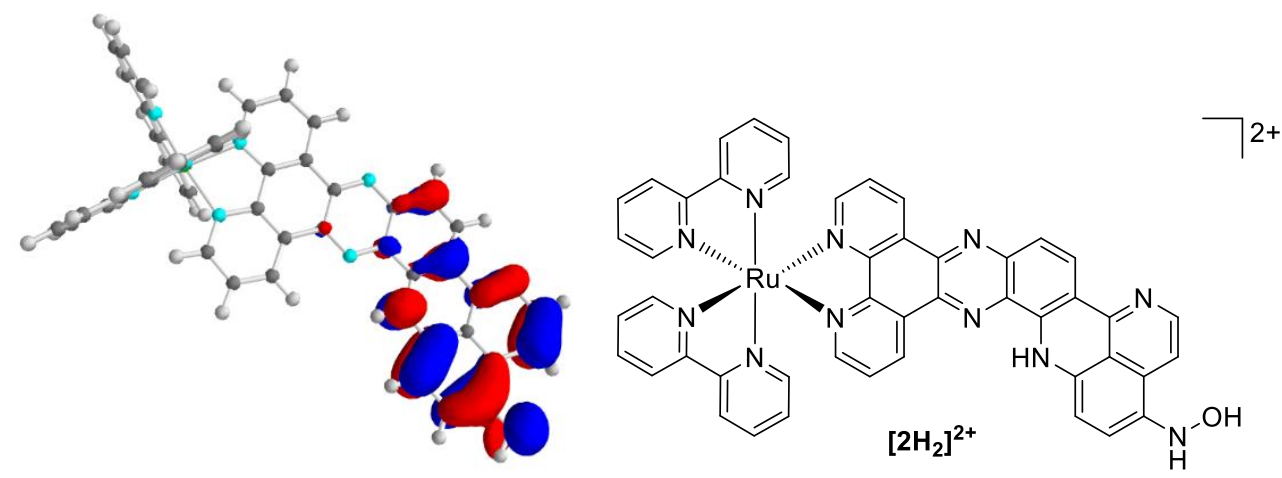
Figure 6. Calculated (B3LYP) isosurfaces of the LUMO of the doubly-reduced doubly-protonated species formed during the photolysis experiment (left) and its corresponding structure (right).

At this stage, a second set of redox potentials were computed for the different protonation states of $[2]^{2+},[2]^{+}$and $[2]^{0}$ and were compared to the related ones calculated for $[1]^{2+},[1]^{+}$and [1] ${ }^{\mathbf{0}}$ (Table S5), in order to estimate the impact of these protonation steps on the reducing power of the charge photoaccumulation system. Charge compensation through protonation is indeed wellknown to stabilize the reduced species, although at the detriment of their reducing strength. For the first reduction process, protonation induces an anodic shift of $+730 \mathrm{mV}$ and $+530 \mathrm{mV}$, for $[\mathbf{1 H}]^{3+}$ $\rightarrow[1 \mathbf{H}]^{2+}$ compared to $[1]^{2+} \rightarrow[1]^{+}$, and $[2 \mathbf{H}]^{3+} \rightarrow[2 \mathbf{H}]^{2+}$ compared to $[2]^{2+} \rightarrow[2]^{+}$, respectively. Charge compensation by protonation has an even more pronounced effect on the second reduction process with shifts of $+950 \mathrm{mV}$ and $+990 \mathrm{mV}$, for $\left[\mathbf{1 H}_{2}\right]^{3+} \rightarrow\left[\mathbf{1 H}_{2}\right]^{2+}$ compared to $[\mathbf{1 H}]^{2+} \rightarrow$ $[1 \mathbf{H}]^{+}$, and $\left[\mathbf{2 H}_{2}\right]^{3+} \rightarrow\left[2 \mathbf{H}_{2}\right]^{2+}$ compared to $[\mathbf{2 H}]^{2+} \rightarrow[2 \mathbf{H}]^{+}$, respectively. When the two complexes are compared, the computed redox potentials are systematically shifted by -200 to $-300 \mathrm{mV}$ to more negative potentials for $[2]^{2+}$ compared to $[1]^{2+}$, demonstrating that the initially calculated trend (Table 1) is maintained in the presence of coupled protonation steps. This confirms the ability of the oxime complex $[2]^{2+}$ to store electrons, under visible light driven conditions, at more negative potentials than the parent complex $[1]^{2+}$.

\section{Conclusion}

In conclusion, we have presented the DFT-guided modification of a charge-accumulating $\mathrm{Ru}(\mathrm{II})$ tris-diimine complex. The target $\mathrm{Ru}(\mathrm{II})$ pyridoquinolinone-oxime complex [2] $\left(\mathrm{PF}_{6}\right)_{2}$ features substantially decreased first and second reduction potentials, shifted by $-0.24 \mathrm{~V}$ and -0.14 $\mathrm{V}$ respectively compared to the parent compound $[1]\left(\mathrm{PF}_{6}\right)_{2}$. This shift closely matches that 
predicted by theoretical methods $(-0.27$ and $-0.17 \mathrm{~V}$, respectively), thus validating our theoretical approach. Photoaccumulation of the doubly reduced species was accomplished by photolysis in the presence of an electron donor, via a two proton, two electron coupled reduction which produced $\left[\mathbf{2 H}_{2}\right]\left(\mathrm{PF}_{6}\right)_{2}$. The effect of the electron-donating oxime substituent persisted in the proton coupled reduction processes and the accumulated electrons have a reducing potential 200 to $300 \mathrm{mV}$ more negative than the former system $\left[\mathbf{1 H}_{2}\right]^{2+}$. Having successfully used our DFT-led approach to modify an existing photoaccumulation scaffold with electron-donating groups in order to lower the potential of multiple stored electrons, we foresee future applications of this system to drive bioinspired multi-electronic catalytic processes.

\section{Experimental Section}

General: The synthesis of $[\mathbf{1}]\left(\mathrm{PF}_{6}\right)_{2}$ was performed according to our previous reports. ${ }^{[51,53]}$ All other chemicals were used as received. Dry solvents were used as purchased from Acros Organics, $\mathrm{CoCp}_{2}$ was purchased from Sigma Aldrich and stored at $-20{ }^{\circ} \mathrm{C}$ in an argon-filled glovebox. ${ }^{1} \mathrm{H}$ and

${ }^{13} \mathrm{C}$ NMR spectra were recorded on a Bruker Avance $400 \mathrm{MHz}$ or $500 \mathrm{MHz}$ NMR spectrometer respectively. UV/vis absorption spectra for determination of the molar extinction coefficient of $[2]^{2+}$ were performed in acetonitrile solution on a Shimadzu $1800 \mathrm{UV} / \mathrm{vis}$ spectrophotometer under atmospheric conditions. All other UV/vis spectra were recorded in dry, degassed acetonitrile on a Cary 60 spectrophotometer in an argon-filled glovebox using a fiber optic cable. Accurate mass measurements (HRMS) were performed on a Bruker maXis mass spectrometer by the "Fédération de Recherche" ICOA/CBM (FR 2708) platform and elemental analysis on a Thermofisher Scientific "Flash 2000" by the "Plateforme d'analyse pour la chimie" (GDS 3648, Strasbourg). 
Computational methods: All DFT calculations were performed with the ADF (Amsterdam Density Functional) code developed by E. J. Baerends and co-workers ${ }^{[61]}$ using triple-zeta basis sets (no frozen core). Geometry optimizations were performed in vacuo relying on the Generalized Gradient Approximation (GGA) VBP exchange-correlation (XC) potential (VWN + BP: Vosko, Wilk \& Nusair ${ }^{[62]}+$ corrective terms by Becke $^{[63]}$ for the exchange, and Perdew ${ }^{[64]}$ for the correlation) with ADF grid precision 6 throughout.

To compute redox potentials $E^{\circ}{ }_{\text {DFT }}(\mathrm{red} / \mathrm{ox})$ relative to the Standard Hydrogen Electrode (SHE), we relied on the standard Born-Haber cycle (Scheme S1) for which the standard Gibbs free energy of a redox half reaction consists of the free energy change in the gas phase $\left(\Delta \mathrm{G}_{\mathrm{in}}\right)$ and the solvation free energies $\left(\Delta \mathrm{G}_{\text {out }}\right)$ of the oxidized (ox) and reduced (red) species of a given redox couple ${ }^{[65,66]}$ :

$$
-n F E^{\circ}{ }_{\text {DFT }}(\text { red } / \text { ox })_{\text {SHE }}=\Delta \mathrm{G}_{\text {in }}+\Delta \mathrm{G}_{\text {out }}+\Delta \mathrm{G}_{\mathrm{SHE}}
$$

$\Delta \mathrm{G}_{\text {in }}$ contains in principle all contributions intrinsic to the cluster itself: $i$ ) the ionization energy of the reduced species, IE(red), which is computed as the enthalpic bonding energy (i.e. electronic internal energy) difference between the two redox partners, $\Delta \mathrm{E}_{\mathrm{B}}=\mathrm{E}_{\mathrm{B}}(\mathrm{ox})-\mathrm{E}_{\mathrm{B}}(\mathrm{red})$, with the VBP XC potential, following Noodleman et al. ${ }^{[67]}$ (for a more general treatment, see Batista et al. ${ }^{[68,69]}$ ); ii) the internal nuclear energy $E_{\text {int }}$ which is the sum of the zero-point energy, $3 \mathrm{kT}$ (i.e. (3/2) kT for translation and (3/2) kT for rotation, therefore (1/2) kT for each degree of freedom), and a small correction term due to the vibrational partition function; iii) the entropic term $-\mathrm{T} \Delta \mathrm{S}$.

In the present case, as we are interested in relative redox potential values (i.e. redox potential values' differences), we won't compute the terms in ii) and iii) as they are expected to contribute only insignificantly to redox potentials' differences (i.e. a few hundredths of Volt). ${ }^{[0]}$

$\Delta \mathrm{G}_{\text {out }}$ contains contributions from the interaction of the complex with its polarizable environment. In the present case, these contributions have been limited to a dimethylformamide solvent outside 
the complex. Solvation energies $\mathrm{E}_{\mathrm{env}}$ have been therefore computed with the COSMO (Conductorlike Screening Model) ${ }^{[71-73]}$ ADF module, representing the solvent as a dielectric continuum. COSMO solvation energies behave according to a Born-like model, that is, they are proportional to $\mathrm{Q}^{2}$ (the total cluster charge squared) multiplied by a factor of $(1-1 / \varepsilon)$. We considered $\varepsilon_{\mathrm{W}}=37$ (via the ADF option: "solv name=dmfa") to mimick an average reaction field response of the environment.

Next, in Eq. $\mathrm{S} 1, \Delta \mathrm{G}_{\mathrm{SHE}}=-4.43 \mathrm{eV}$ is defined at $\mathrm{pH}=0 .{ }^{[74]}$ For higher $\mathrm{pH}$ values, $\Delta \mathrm{G}_{\mathrm{SHE}}$ increases by $0.059 \mathrm{eV}$ per $\mathrm{pH}$ unit, so (for example) under standard physiological conditions at $\mathrm{pH}=7, \Delta \mathrm{G}_{\text {SHE }}$ shifts to $-4.02 \mathrm{eV}$. We will proceed below via a calibration procedure between computed (ref. SHE) and experimental (ref. $\mathrm{Fc} / \mathrm{Fc}^{+}$) redox potentials for the $\mathrm{Ru}$ complex with the dipyridophenazine (dppz)-pyridoquinolinone ligand, and the intercept value will implicitly contain all constant corrections (including the $0.4 \mathrm{~V}$ difference between SHE and Fc references.

Finally, $\mathrm{F}$ is the Faraday constant (here: 1 elementary electric charge) and $\mathrm{n}=1$ for a one-electron reduction.

For the parent complex $[1]\left(\mathrm{PF}_{6}\right)_{2}$, a plot of the experimental redox potential values $\left(\mathrm{ref} . \mathrm{Fc} / \mathrm{Fc}^{+}\right)$ against DFT computed values (ref. SHE) yields:

$$
\mathrm{E}^{\circ}\left(\exp . v s . \mathrm{Fc}^{+} / \mathrm{Fc}\right)=1.0811 \times \mathrm{E}^{\circ}(\mathrm{DFT} \text { vs. } \mathrm{SHE})-0.609
$$

${ }^{1} \mathrm{H}$ and ${ }^{13} \mathrm{C}$ screening constants for both oxime and nitrosyl tautomers have been computed by DFT (ADF code) via its NMR sub-module (same technical DFT details as for the computation of redox potentials above).

Synthesis of [2](PF $)_{2}:$ [1] $\left(\mathrm{PF}_{6}\right)_{2}(50 \mathrm{mg}, 0.044 \mathrm{mmol})$, hydroxylamine hydrochloride (77 mg, 0.92 mmol), and pyridine (72 $\mu \mathrm{L}, 0.89 \mathrm{mmol})$ were dissolved in a 2:2:1 mixture of acetonitrile:ethanol:water $(12 \mathrm{~mL})$ in a schlenk tube in the dark under ambient atmosphere. The 
mixture was heated to $60{ }^{\circ} \mathrm{C}$ for 72 hours. The reaction mixture was quenched in the dark with a saturated solution of $\mathrm{KPF}_{6}(\mathrm{aq})(12 \mathrm{~mL})$. The resulting solid was collected by suction filtration in low light and washed well with water and the crude product was passed through the fritted glass funnel with acetonitrile. The solvent was removed in vacuo, the product was dissolved in a minimum of acetonitrile and precipitated with diethyl ether. The product was collected by suction filtration, washed well with diethyl ether and dried on high vacuum to yield the pure product as a red-orange solid (32 $\mathrm{mg}, 0.028 \mathrm{mmol}, 63 \%$ yield), subsequently stored in clear glass containers without evidence of photodegradation. For elemental analysis, additional purification was performed by column chromatography on alumina (from $10 \%$ to $40 \%$ of aq. $\mathrm{KNO}_{3}(10 \% \mathrm{v} / \mathrm{v}$ Sat. $\mathrm{KNO}_{3}$ in deionized $\left.\mathrm{H}_{2} \mathrm{O}\right)$ in $\left.\mathrm{CH}_{3} \mathrm{CN}\right)$ and anion exchange from [2] $\left(\mathrm{NO}_{3}\right)_{2}$ to [2] $\left(\mathrm{PF}_{6}\right)_{2}$ was performed by precipitation with saturated $\mathrm{KPF}_{6} .{ }^{1} \mathrm{H}$ NMR $(0.43 \mathrm{mM} 338 \mathrm{~K}, 400 \mathrm{MHz}, \delta$, ppm) $10.12(\mathrm{~d}, J=8.3 \mathrm{~Hz}, 1 \mathrm{H}), 9.81(\mathrm{~d}, J=8.2 \mathrm{~Hz}, 1.4 \mathrm{H}), 9.73(\mathrm{~d}, J=9.2 \mathrm{~Hz}, 1.2 \mathrm{H}), 9.56 J=4.4 \mathrm{~Hz}$, 1H), $8.73(\mathrm{~d}, J=9.3 \mathrm{~Hz}, 0.9 \mathrm{H}), 8.56$ (t, br, $J=10.8 \mathrm{~Hz}, 6.8 \mathrm{H}), 8.25$ (t, $J=4.2 \mathrm{~Hz}, 4.1 \mathrm{H}), 8.15$ (t, $J=7.9 \mathrm{~Hz}, 3.3 \mathrm{H}), 8.03$ (t, br, $J=6.5 \mathrm{~Hz}, 3.3 \mathrm{H}), 7.98$, (sept, $J=2.8 \mathrm{~Hz}, 3.4 \mathrm{H}), 7.90$ (d, br, J = $5.6 \mathrm{~Hz}, 3.3 \mathrm{H}$ ), $7.80(\mathrm{q}, \mathrm{br}, J=4.6 \mathrm{~Hz}, 3.1 \mathrm{H}), 7.50(\mathrm{t}, J=6.70 \mathrm{~Hz}, 3.0 \mathrm{H}), 7.29$ (quart, $J=6.1 \mathrm{~Hz}$, 3.1 H), 6.82-6.95 (m, 1.2H), 6.17 (s, 0.8H). ${ }^{13} \mathrm{C}$ NMR (3.5 mM, $318 \mathrm{~K}, 126 \mathrm{MHz}, \delta$, ppm) 179.9, 157.3, 157.1, 156.4, 154.1, 153.9, 153.6, 152.6, 152.0, 150.6, 150.3, 146.5, 145.6, 143.0, 141.7, $140.3,139.6,138.1,138.0,135.4,134.4,133.7,130.8,130.3,130.0,127.7,127.4,124.4,124.3$, 120.0, 101.8. HRMS (m/z): $\left(\mathrm{M}^{2+}\right)$ calc $\left(\mathrm{C}_{47} \mathrm{H}_{29} \mathrm{~N}_{11} \mathrm{ORu}\right): 432.579453$ found: 432.5797 . Elemental Analysis calc $\left(\mathrm{C}_{47} \mathrm{H}_{29} \mathrm{~N}_{11} \mathrm{ORuP}_{2} \mathrm{~F}_{12}+0.5 \mathrm{H}_{2} \mathrm{O}+0.3 \mathrm{KPF}_{6}\right): \mathrm{C} 46.76 \% \mathrm{H} 2.50 \% \mathrm{~N} 12.76 \%$ Found: C $46.89 \%, \mathrm{H} 2.75 \%, \mathrm{~N} 12.90 \%$.

(Spectro)electrochemistry experiments: Cyclic and differential pulse voltammetry measurements were performed using a Metrohm Autolab PGSTAT100N potentiostat in a $0.1 \mathrm{M}$ 
solution of tetrabutylammonium hexafluorophosphate $\left(n \mathrm{Bu}_{4} \mathrm{NPF}_{6}\right)$ in dry, degassed DMF under argon. The concentration of $[2]\left(\mathrm{PF}_{6}\right)_{2}$ was $0.3 \mathrm{mM}$. The counter electrode was a platinum wire, and the working electrode was a $3 \mathrm{~mm}$ glassy carbon disc. All voltammograms were performed using a saturated $\mathrm{Ag} / \mathrm{AgCl}$ pseudo-reference electrode and internally referenced to the ferrocene/ferrocenium $\left(\mathrm{Fc}^{+} / \mathrm{Fc}\right)$ redox couple. Cyclic voltammograms were recorded at a scan rate of $100 \mathrm{mV} \mathrm{s}^{-1}$. Differential pulse voltammograms were recorded in a negative sweep direction with a step size of $-0.005 \mathrm{~V}$, a modulation amplitude of $0.025 \mathrm{~V}$, modulation time $0.05 \mathrm{~s}$, and an interval time of $0.5 \mathrm{~s}$.

Spectroelectrochemical measurements were carried out on a $0.25 \mathrm{mM}$ solution of [2] $\left(\mathrm{PF}_{6}\right)_{2}$ in 0.1 $\mathrm{M} n \mathrm{Bu}_{4} \mathrm{PF}_{6}$ in a 3 electrode cell with a $1 \mathrm{~mm}$ path length. The working electrode was a $\mathrm{Pt}$ mesh electrode, the counter electrode was a Pt wire and the reference electrode was a saturated $\mathrm{Ag} / \mathrm{AgCl}$ electrode. A bias of $-0.3 \mathrm{~V}$ vs. $\mathrm{Ag} / \mathrm{AgCl}$ was applied and UV/vis absorbance spectra were recorded over 5 min with no change observed. The potential was decreased to $-0.75 \mathrm{~V}$ (or $-1.0 \mathrm{~V}$ as indicated) vs. $\mathrm{Ag} / \mathrm{AgCl}$ for $30 \mathrm{~min}$, with no further evolution observed after approximately $15 \mathrm{~min}$. Finally, the voltage was increased to $+0.1 \mathrm{~V}$ vs. $\mathrm{Ag} / \mathrm{AgCl}$ for 20 min leading to the complete return to the original [2] ${ }^{2+}$ spectrum.

Chemical reduction with cobaltocene: ${ }^{[51]}$ All chemical reduction experiments were performed in an argon-filled glovebox. UV/vis spectra were recorded in dry, degassed acetonitrile on a Cary 60 spectrophotometer using a fiber optic cable. All spectra were zeroed at $800 \mathrm{~nm}$ and corrected for increasing volume. The concentration of $\mathrm{CoCp}_{2}$ solution used for the titration was determined by adding $30 \mu \mathrm{L}$ aliquots of $\mathrm{CoCp}_{2}$ solution to $3.0 \mathrm{ml}$ of acetonitrile. The concentration was determined by measuring the change in absorbance at $327 \mathrm{~nm}$ between successive additions of $\mathrm{CoCp}_{2}$ using the known extinction coefficient for $\mathrm{CoCp}_{2}$ in ethanol of $7420 \mathrm{~L} \mathrm{~mol}^{-1} \mathrm{~cm}^{-1} \cdot{ }^{[75]}$ Using 
the calculated concentration of $0.36 \mathrm{mM}$, it was determined that the first $\sim 0.2$ eq of $\mathrm{CoCp}_{2}$ added to the dry degassed acetonitrile solution were used to quench residual oxygen. ${ }^{[29,51]}$ To perform the chemical reduction titration of $[2]\left(\mathrm{PF}_{6}\right)_{2}$, aliquots of the $\mathrm{CoCp} 2$ solution $(0.36 \mathrm{mM})$ were then added to a $2.5 \mathrm{ml}$ solution of $[2]\left(\mathrm{PF}_{6}\right)_{2}(0.021 \mathrm{mM})$ in dry degassed acetonitrile and after each addition, the UV/vis absorbance spectrum was recorded. To probe the reversibility of the reduction in the presence of oxygen the solution was then removed from the glovebox and exposed to air (with gentle shaking) for $10 \mathrm{~min}$. The headspace of the cuvette was then flushed with argon and the cuvette was replaced in the glove box and the final UV/vis absorbance spectrum was collected.

\section{Chemical reduction of [2](PF6)2 with cobaltocene in the presence of TFA: ${ }^{[51]}$ Prior to chemical} reduction in the presence of TFA, a chemical reduction titration was carried out with the above procedure to determine the exact volume of 1 equivalent of $\mathrm{CoCp}_{2}$ stock solution. Addition of TFA stock solution $(1.5 \mathrm{mM})$ was carried out in $21 \mu \mathrm{L}$ (1 eq.) increments. $\mathrm{CoCp}_{2}$ and TFA additions were carried out sequentially in fresh solutions of $12 \mu \mathrm{M}[2]\left(\mathrm{PF}_{6}\right)_{2}$ in dry degassed $\mathrm{CH}_{3} \mathrm{CN}$ to determine possible effects of the order of addition of reducing agent and proton source.

EPR spectroscopy experiments: Spectra were recorded at room temperature on a Bruker ER200D X-band CW EPR spectrometer with an ER-4104OR cavity with the following instrument parameters: microwave frequency, $9.53 \mathrm{GHz}$; microwave power, $3.17 \mathrm{~mW}$; modulation amplitude, $0.1 \mathrm{mT}$; modulation frequency, $100 \mathrm{KHz}$; number of scan, $219[2]^{+}$and $40[1]^{+}$. Simulations were performed with the Matlab toolbox Easyspin (version 5.2.20). For [2] ${ }^{+}$, initial isotropic hyperfine couplings were based on $[1]^{+}$EPR and DFT data, ${ }^{[51]}$ and optimized with using DFT-optimized lowest energy structure for $[2]^{+}$. Sample preparations for EPR spectroscopy were carried out in an argon-filled glovebox using dry and degassed solvent. To record the spectrum of the singly-reduced complex, a $1 \mathrm{~mm}$ quartz cuvette $(300 \mu \mathrm{L})$ was filled with a $200 \mu \mathrm{M}$ solution of [2](PF6)2 (or 
[1] $\left.\left(\mathbf{P F}_{6}\right)\right)$ in acetonitrile. The chemical reduction was carried out by adding aliquots of a $\mathrm{CoCp}_{2}$ stock solution (50 $\mathrm{mM}$ in acetonitrile) and was monitored by UV-vis absorption. The solution was then transferred inside the glovebox into a flat cell fitted with Young valves. The spin concentration of $[2]^{+}$and $[1]^{+}$was determined by comparing the EPR signal intensity with that of a solution of (2,2,6,6-Tetramethylpiperidin-1-yl)oxyl of known concentration measured under the same conditions using double integration. ${ }^{[76,77]}$ Percentage spin yields were of [2] $]^{+}$and $[1]^{+}$respectively relative to the $200 \mu \mathrm{M}$ concentration of the sample.

To record the spectrum of the doubly-reduced complex $[2]^{0}$, bulk electrochemical reduction of $[2]^{2+}$ was performed on a $240 \mu \mathrm{M}$ solution of [2] $\left(\mathrm{PF}_{6}\right)_{2}$ in $0.1 \mathrm{M} n \mathrm{Bu}_{4} \mathrm{NPF}_{6}$ dissolved in DMF. The working electrode was a Pt mesh electrode, the counter electrode was a Pt wire, and the pseudo reference electrode was a Ag wire. A cyclic voltammogram was performed to determine the potential of the second reduction of $[2]^{2+}$ with reference to the Ag wire. Bulk reduction was performed by chronoamperometry for $3.5 \mathrm{~h}$ at $-1.0 \mathrm{~V}$ vs silver wire (a sufficiently negative potential to perform the second reduction of $[2]^{2+}$ at $-1.46 \mathrm{~V} v s \mathrm{Fc}^{+} / \mathrm{Fc}$ ). After $90 \mathrm{~min}$, a $300 \mu \mathrm{L}$ sample was removed and analyzed by UV/vis absorbance spectroscopy, the resulting spectrum matched that of $[2]^{0}$ determined by spectroelectrochemistry. The $300 \mu \mathrm{L}$ sample was subsequently transferred to a flat EPR cell for analysis. The spin concentration of $[2]^{0}$ was determined by comparing the EPR signal intensity with that of a solution of (2,2,6,6-Tetramethylpiperidin-1-yl)oxyl of known concentration, recorded in the same electrolyte solution, using the double integration method (see above).

Photolysis experiments: Sample preparation and photolysis experiments were carried out in an argon-filled glovebox in low-light conditions. To prepare the photolysis solution $6.0 \mu \mathrm{L}$ of triethylamine was dissolved in $2.7 \mathrm{~mL}$ of dry degassed acetonitrile (final concentration $\mathrm{Et}_{3} \mathrm{~N}=160$ 
$\mathrm{mM})$. To this was added $0.030 \mathrm{~mL}$ of $[2]\left(\mathrm{PF}_{6}\right)_{2}$ stock solution $(1.38 \mathrm{mM})$ to a final concentration of $15 \mu \mathrm{M}[2]\left(\mathrm{PF}_{6}\right)_{2}$ in the photolysis solution. The solution was irradiated using a $300 \mathrm{~W}$ ozonefree xenon arc lamp (Newport Ltd.) operated at $280 \mathrm{~W}$ with a $400 \mathrm{~nm} \mathrm{UV} \mathrm{cutoff} \mathrm{filter.} \mathrm{UV/Vis}$ absorbance spectra changes were monitored using a UV/Vis spectrometer after closing the irradiation shutter. After spectral change ceased the cuvette was covered in foil, removed from the glovebox and exposed to air for $\sim 5$ minutes. The cuvette was re-sealed in ambient atmosphere, shaken gently, inserted into the glovebox, and the final UV/Vis absorbance spectrum was performed to assess the reversibility of photoaccumulation.

\section{Acknowledgements}

Sebastian Bold is acknowledged for his help in fitting the UV/vis absorption data. This work was supported by the Labex program ARCANE (ANR-11-LABX-0003-01), the graduate school in Chemistry, Biology and Health of Univ. Grenoble Alpes (CBH-EUR-GS, ANR-17-EURE-0003) and the CEA DRF Impulsion 2017 program.

\section{References}

[1] A. Thapper, S. Styring, G. Saracco, A. W. Rutherford, B. Robert, A. Magnuson, W. Lubitz, A. Llobet, P. Kurz, A. Holzwarth, S. Fiechter, H. deGroot, S. Campagna, A. Braun, H. Bercegol, V. Artero, Green 2013, 3, 43-57.

[2] T. Faunce, S. Styring, M. R. Wasielewski, G. W. Brudvig, A. W. Rutherford, J. Messinger, A. F. Lee, C. L. Hill, H. deGroot, M. Fontecave, D. R. MacFarlane, B. Hankamer, D. G. 
Nocera, D. M. Tiede, H. Dau, W. Hillier, L. Wang, R. Amal, Energy Environ. Sci. 2013, 6, 1074-1076.

[3] T. A. Faunce, W. Lubitz, A. W. Rutherford, D. MacFarlane, G. F. Moore, P. Yang, D. G. Nocera, T. A. Moore, D. H. Gregory, S. Fukuzumi, K. B. Yoon, F. A. Armstrong, M. R. Wasielewski, S. Styring, Energy Environ. Sci. 2013, 6, 695-698.

[4] http://www. euchems.eu/solar-driven-chemistry

[5] S. Roy, M. Bacchi, G. Berggren, V. Artero, ChemSusChem 2015, 8, 3632-3638.

[6] N. Queyriaux, R. T. Jane, J. Massin, V. Artero, M. Chavarot-Kerlidou, Coord. Chem. Rev. 2015, 304-305, 3-19.

[7] R. S. Khnayzer, V. S. Thoi, M. Nippe, A. E. King, J. W. Jurss, K. A. El Roz, J. R. Long, C. J. Chang, F. N. Castellano, Energy Environ. Sci. 2014, 7, 1477-1488.

[8] D. Z. Zee, T. Chantarojsiri, J. R. Long, C. J. Chang, Acc. Chem. Res. 2015, 48, 2027-2036.

[9] M. A. Gross, C. E. Creissen, K. L. Orchard, E. Reisner, Chem. Sci. 2016, 7, 5537-5546.

[10] M. A. Gross, A. Reynal, J. R. Durrant, E. Reisner, J. Am. Chem. Soc. 2014, 136, 356-366.

[11] Y. Pellegrin, L. Le Pleux, E. Blart, A. Renaud, B. Chavillon, N. Szuwarski, M. Boujtita, L. Cario, S. Jobic, D. Jacquemin, F. Odobel, J. Photochem. Photobiol. Chem. 2011, 219, 235242.

[12] M. Gennari, F. Légalité, L. Zhang, Y. Pellegrin, E. Blart, J. Fortage, A. M. Brown, A. Deronzier, M.-N. Collomb, M. Boujtita, D. Jacquemin, L. Hammarström, F. Odobel, J. Phys. Chem. Lett. 2014, 5, 2254-2258.

[13] B. Matt, X. Xiang, A. L. Kaledin, N. N. Han, J. Moussa, H. Amouri, S. Alves, C. L. Hill, T. Q. Lian, D. G. Musaev, G. Izzeta, A. Proust, Chem. Sci. 2013, 4, 1737-1745.

[14] A. Panagiotopoulos, K. Ladomenou, D. Sun, V. Artero, A. G. Coutsolelos, Dalton Trans. 2016, 45, 6732-6738.

[15] L. Mintrop, J. Windisch, C. Gotzmann, R. Alberto, B. Probst, P. Kurz, J. Phys. Chem. B 2015, 119, 13698-13706.

[16] K. Ladomenou, M. Natali, E. Iengo, G. Charalampidis, F. Scandola, A. G. Coutsolelos, Coord. Chem. Rev. 2015, 304-305, 38-54.

[17] P. B. Pati, L. Zhang, B. Philippe, R. Fernández-Terán, S. Ahmadi, L. Tian, H. Rensmo, L. Hammarström, H. Tian, ChemSusChem 2017, 10, 2480-2495. 
[18] R. J. Kamire, M. B. Majewski, W. L. Hoffeditz, B. T. Phelan, O. K. Farha, J. T. Hupp, M. R. Wasielewski, Chem. Sci. 2017, 8, 541-549.

[19] N. Kaeffer, J. Massin, C. Lebrun, O. Renault, M. Chavarot-Kerlidou, V. Artero, J. Am. Chem. Soc. 2016, 138, 12308-12311.

[20] L. Hammarström, Acc. Chem. Res. 2015, 48, 840-850.

[21] Y. Pellegrin, F. Odobel, Coord. Chem. Rev. 2011, 255, 2578-2593.

[22] A. G. Bonn, O. S. Wenger, Chimia 2015, 69, 17-21.

[23] V. Artero, J.-M. Saveant, Energy Environ. Sci. 2014, 7, 3808-3814.

[24] M. P. O’Neil, M. P. Niemczyk, W. A. Svec, D. Gosztola, G. L. Gaines, M. R. Wasielewski, Science 1992, 257, 63-65.

[25] M. Elvington, K. J. Brewer, Inorg. Chem. 2006, 45, 5242-5244.

[26] R. Konduri, H. Ye, F. M. MacDonnell, S. Serroni, S. Campagna, K. Rajeshwar, Angew. Chem. Int. Ed. 2002, 41, 3185-3187.

[27] R. Konduri, N. R. de Tacconi, K. Rajeshwar, F. M. MacDonnell, J. Am. Chem. Soc. 2004, $126,11621-11629$.

[28] N. R. de Tacconi, R. O. Lezna, R. Konduri, F. Ongeri, K. Rajeshwar, F. M. MacDonnell, Chem.- Eur. J. 2005, 11, 4327-4339.

[29] S. Singh, N. R. de Tacconi, N. R. G. Diaz, R. O. Lezna, J. Muñoz Zuñiga, K. Abayan, F. M. MacDonnell, Inorg. Chem. 2011, 50, 9318-9328.

[30] M. Kuss-Petermann, M. Orazietti, M. Neuburger, P. Hamm, O. S. Wenger, J. Am. Chem. Soc. 2017, 139, 5225-5232.

[31] J. Nomrowski, O. S. Wenger, J. Am. Chem. Soc. 2018, 140, 5343-5346.

[32] J. Nomrowski, X. Guo, O. S. Wenger, Chem. - Eur. J. 2018, 24, 14084-14087.

[33] M. Kuss-Petermann, O. S. Wenger, Chem. - Eur. J. 2017, 23, 10808-10814.

[34] M. Orazietti, M. Kuss-Petermann, P. Hamm, O. S. Wenger, Angew. Chem. Int. Ed. 2016, 55, 9407-9410.

[35] M. Skaisgirski, X. Guo, O. S. Wenger, Inorg. Chem. 2017, 56, 2432-2439.

[36] K. J. Elliott, A. Harriman, L. Le Pleux, Y. Pellegrin, E. Blart, C. R. Mayer, F. Odobel, Phys. Chem. Chem. Phys. 2009, 11, 8767-8773.

[37] B. Matt, J. Fize, J. Moussa, H. Amouri, A. Pereira, V. Artero, G. Izzet, A. Proust, Energy Environ. Sci. 2013, 6, 1504-1508. 
[38] K. Kitamoto, M. Ogawa, G. Ajayakumar, S. Masaoka, H.-B. Kraatz, K. Sakai, Inorg. Chem. Front. 2016, 3, 671-680.

[39] K. Kobayashi, H. Ohtsu, K. Nozaki, S. Kitagawa, K. Tanaka, Inorg. Chem. 2016, 55, 20762084.

[40] T. Fukushima, T. Wada, H. Ohtsu, K. Tanaka, Dalton Trans. 2010, 39, 11526-11534.

[41] D. Polyansky, D. Cabelli, J. T. Muckerman, E. Fujita, T. Koizumi, T. Fukushima, T. Wada, K. Tanaka, Angew. Chem. Int. Ed. 2007, 46, 4169-4172.

[42] L. Zedler, S. Kupfer, I. R. de Moraes, M. Wächtler, R. Beckert, M. Schmitt, J. Popp, S. Rau, B. Dietzek, Chem.- Eur. J. 2014, 20, 3793-3799.

[43] S. Kupfer, Phys. Chem. Chem. Phys. 2016, 18, 13357-13367.

[44] J. M. Aslan, D. J. Boston, F. M. MacDonnell, Chem.- Eur. J. 2015, 21, 17314-17323.

[45] S. Mendes Marinho, M.-H. Ha-Thi, V.-T. Pham, A. Quaranta, T. Pino, C. Lefumeux, T. Chamaillé, W. Leibl, A. Aukauloo, Angew. Chem. Int. Ed. 2017, 56, 15936-15940.

[46] N. R. de Tacconi, R. Chitakunye, F. M. MacDonnell, R. O. Lezna, J. Phys. Chem. A 2008, $112,497-507$.

[47] M. B. Majewski, N. R. de Tacconi, F. M. MacDonnell, M. O. Wolf, Chem. - Eur. J. 2013, 19, 8331-8341.

[48] E. A. Gibson, Chem. Soc. Rev. 2017, 46, 6194-6209.

[49] V. Nikolaou, A. Charisiadis, G. Charalambidis, A. G. Coutsolelos, F. Odobel, J. Mater. Chem. A 2017, 5, 21077-21113.

[50] J. Schindler, Y. Zhang, P. Traber, J.-F. Lefebvre, S. Kupfer, M. Demeunynck, S. Gräfe, M. Chavarot-Kerlidou, B. Dietzek, J. Phys. Chem. C 2018, 122, 83-95.

[51] J.-F. Lefebvre, J. Schindler, P. Traber, Y. Zhang, S. Kupfer, S. Gräfe, I. Baussanne, M. Demeunynck, J.-M. Mouesca, S. Gambarelli, V. Artero, B. Dietzek, M. Chavarot-Kerlidou, Chem. Sci. 2018, 9, 4152-4159.

[52] J. Barber, Chem. Soc. Rev. 2009, 38, 185-196.

[53] J.-F. Lefebvre, D. Saadallah, P. Traber, S. Kupfer, S. Grafe, B. Dietzek, I. Baussanne, J. De Winter, P. Gerbaux, C. Moucheron, M. Chavarot-Kerlidou, M. Demeunynck, Dalton Trans. 2016, 45, 16298-16308.

[54] L. Bouffier, M. Demeunynck, A. Milet, P. Dumy, J. Org. Chem. 2004, 69, 8144-8147.

[55] K. Ritter, C. Pehlken, D. Sorsche, S. Rau, Dalton Trans. 2015, 44, 8889-8905. 
[56] L. C. Anderson, R. L. Yanke, J. Am. Chem. Soc. 1934, 56, 732-735.

[57] N. G. Connelly, W. E. Geiger, Chem. Rev. 1996, 96, 877-910.

[58] J. Fees, W. Kaim, M. Moscherosch, W. Matheis, J. Klima, M. Krejcik, S. Zalis, Inorg. Chem. 1993, 32, 166-174.

[59] Y. Pellegrin, F. Odobel, Comptes Rendus Chim. 2017, 20, 283-295.

[60] Disproportionation of the singly-reduced singly-protonated $[\mathbf{2 H}]^{2+}$ species is calculated to be thermodynamically favored and is supported by the analysis and fit of the UV-visible absorption data (Figure S16).

[61] G. te Velde, E. J. Baerends, J. Comput. Phys. 1992, 99, 84-98.

[62] S. H. Vosko, L. Wilk, M. Nusair, Can. J. Phys. 1980, 58, 1200-1211.

[63] A. D. Becke, Phys. Rev. A 1988, 38, 3098-3100.

[64] J. P. Perdew, Phys. Rev. B 1986, 33, 8822-8824.

[65] J.-M. Mouesca, J. L. Chen, L. Noodleman, D. Bashford, D. A. Case, J. Am. Chem. Soc. 1994, $116,11898-11914$.

[66] B. S. Perrin, T. Ichiye, Proteins Struct. Funct. Bioinf. 2010, 78, 2798-2808.

[67] R. A. Torres, T. Lovell, L. Noodleman, D. A. Case, J. Am. Chem. Soc. 2003, 125, 1923-1936.

[68] L. E. Roy, E. R. Batista, P. J. Hay, Inorg. Chem. 2008, 47, 9228-9237.

[69] LE Roy, E Jakubikova \& ER Batista: www.researchgate.net/file.PostFileLoader.html?id=56673ec760614bd8848b4568\&assetKey $=\mathrm{AS} \% 3 \mathrm{~A} 304487376326658 \% 401449606855955$

[70] A. Volbeda, J. M. Mouesca, C. Darnault, M. M. Roessler, A. Parkin, F. A. Armstrong, J. C. Fontecilla-Camps, Chem. Commun. 2018, 54, 7175-7178.

[71] A. Klamt, G. Schüürmann, J. Chem. Soc. Perkin Trans. 2 1993, 799-805.

[72] A. Klamt, J. Phys. Chem. 1995, 99, 2224-2235.

[73] A. Klamt, V. Jonas, J. Chem. Phys. 1996, 105, 9972-9981.

[74] H. Reiss, A. Heller, J. Phys. Chem. 1985, 89, 4207-4213.

[75] A. Jaworska-Augustyniak, J. Wojtczak, Monatshefte Für Chem. Chem. Mon. 1979, 110, 1113-1121.

[76] Randolph, M L (1972) Quantitative Considerations in Electron Spin Resonance Studies of Biological Materials, in Biological Applications of Electron Spin Resonance (Swartz, H M, Bolton, J R, and Borg, D C, Eds.), Wiley-Interscience, New York, 119-133. 
[77] N. D. Yordanov, Appl. Magn. Reson. 1994, 6, 241-257. 